\title{
Primary oat cell carcinoma of the oesophagus
}

\author{
SABARATNAM SABANATHAN, GEOFFREY P GRAHAM, FAYEK D SALAMA
}

Department of Thoracic Surgery, City Hospital, Nottingham

ABSTRACT Three cases of oat cell carcinoma of the oesophagus are presented and published reports reviewed. This is mainly a disease of older age with a 3:2 predominance of men. Of all published cases, $43(47.3 \%)$ occurred in the middle third, $41(45.1 \%)$ in the lower third, and four $(4.4 \%)$ in the्र upper third. In one case it was multifocal and in two the location was not stated. Dysphagia wast the most common symptom and was found in $82.5 \%$ of cases. Overall survival was 4.7 months. The् longest survival in a patient treated by resection was 24 months and in a patient treated by chemotherapy 11 months. All but one of the patients had widely disseminated metastatic disease a $b$ death. It is concluded that surgery, possibly with adjuvent chemotherapy, holds out the best prospect for such patients.

Since the original description of this condition by McKeown ${ }^{1}$ in 1952, 88 cases of oat cell carcinoma have been reported. ${ }^{1-29}$ These cases had both the clinical and histologic characteristics of oat cell lung cancer, with a rapidly fatal course when untreated. The pathology is characteristic and has been well described in pathology journals, where most of the cases have been reported. The purpose of this paper is to review the available clinical information on this entity and to present three cases of our own.

\section{Patients and findings}

\section{THE PRESENT CASES}

Case 1

A 74 year old woman presented in December 1978 with a two month history of dysphagia and lower retrosternal pain radiating to the back. A barium swallow showed an irregular filling defect in the lower end of the oesophagus. Physical findings, laboratory results, and chest radiograph appearances were all within normal limits. Oesophagoscopy showed a tumour arising $34 \mathrm{~cm}$ from the incisors. A biopsy showed that the subepithelial tissues were infiltrated by an oat cell carcinoma. The patient underwent distal oesophagectomy with oesophagogastrostomy. At operation the tumour was found in the lower third of

Address for reprint requests: Mr FD Salama FRCS, City Hospital, Nottingham NG5 IPB

Accepted 20 September 1985 the oesophagus. There was also a small nodule in the parietal pleura overlying the aorta and some enlarged glands along the left gastric vessels. All obvious tumour was excised at operation. The patient waso discharged on the 12th postoperative day after ano uneventful recovery. Microscopic examination of the specimen showed oat cell carcinoma of the oesophagus infiltrating the whole of the oesophagea $\mathrm{B}$ wall. The pleural nodule and left gastric lymph nodes? contained metastatic tumour.

The patient died three months later; postmortem examination showed widespread metastatic disease in? the liver, peritoneum, and left adrenal gland.

\section{Case 2}

A 78 year old woman with four week history of dys $\delta$ phagia was found to have an irregular filling defect in? the mid oesophagus on barium swallow examinationg in December 1980. An ulcerating lesion was found $28 \mathrm{~cm}$ from the incisiors on oesophagoscopy and the biopsy showed oat cell carcinoma. A chest radiograph was normal and there was no evidence of metastases on clinical examination or on isotope scans of livef and bone. Because of her poor general condition she् was referred for palliative radiotherapy. She had sube jective improvement of her dysphagia, but died ab home six weeks after diagnosis; permission for post mortem examination was refused.

\section{Case 3}

A 55 year old woman presented in May 1985 with three week history of retrosternal pain on eating, which radiated to the back, and dysphagia. Clinica 


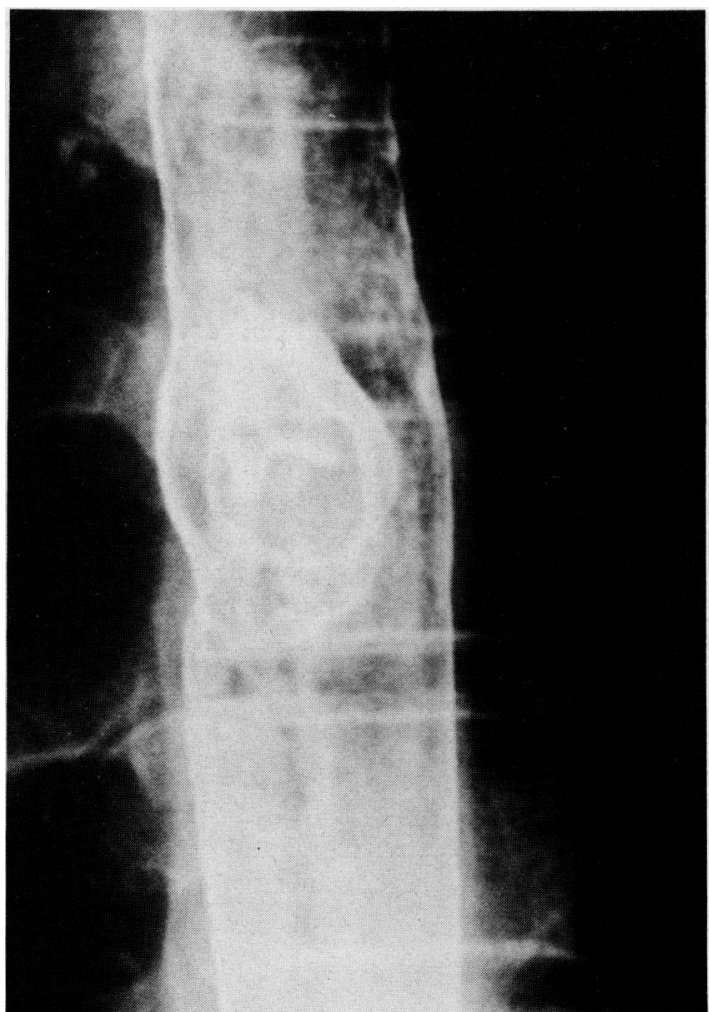

Barium swallow from case 3 showing a polypoid flling in the mid oesophagus.

examination showed nothing abnormal. A barium swallow examination showed a polypoid mass in the mid thoracic oesophagus (figure). Oesophagoscopy showed tumour arising $30 \mathrm{~cm}$ from the incisors. Histological examination of the biopsy specimen showed oat cell carcinoma. Chest radiography, bronchoscopy, and isotope scanning of the liver showed nothing abnormal. The patient underwent an IvorLewis oesophagectomy and oesophagogastrostomy. Recovery was uneventful and at follow up three months later the patient was doing well. The resected specimen contained a polypoid mass $6.25 \mathrm{~cm}$ in diameter, which on microscopic examination proved to be an oat cell carcinoma with small areas of sqamous differentiation. It had not infiltrated the muscle and the attached lymph nodes were tumour free.

\section{PUBLISHED CASES}

\section{Clinical features}

In the present series of 91 cases (which include our own) there were 54 men $(59.3 \%)$ and 37 women $(40.7 \%)$. Ages ranged from 29 to 88 years, with a mean of 64.5 . Most cases $(73.6 \%)$ were diagnosed in the sixth, seventh, and eighth decades. The reported incidence varies from $0.05 \%{ }^{4}$ to $7.6 \%{ }^{9}$ of all carcinomas of the oesophagus. Briggs and Ibrahim, ${ }^{21}$ who have published the largest series, gave an incidence of 23 out of 955 cases $(2.4 \%)$.

Dysphagia was the most common symptom and was found in $82.5 \%$ of cases. The duration of symptoms varied from two weeks to two years (mean 3.2 months). Ectopic endocrine syndromes were noted in two cases. ${ }^{1327}$ One patient had inappropriate antidiuretic hormone secretion ${ }^{27}$ and the other presented with hypercalcaemia, which resolved after radiotherapy but recurred with tumour recurrence. ${ }^{13}$

\section{Pathology}

Forty three oat cell carcinomas of the oesophagus $(47.3 \%$ of the total) occurred in the middle third, 41 $(45.1 \%)$ in the lower third, and four $(4.4 \%)$ in the upper third. The location was not stated in two cases. An apparent multifocal origin was reported in one case. ${ }^{22}$ Macroscopically, oat cell carcinomas were either polypoid $(47.5 \%)$, fugating $(15 \%)$, ulcerating $(15 \%)$, or stenotic $(22.5 \%)$. Mircoscopically, 67 $(73.6 \%)$ were pure oat cell carcinomas and the rest

Results of treatment

\begin{tabular}{|c|c|c|c|c|c|c|}
\hline \multirow[t]{2}{*}{ Treatment } & \multirow[t]{2}{*}{ No of patients } & \multirow{2}{*}{$\begin{array}{l}\text { Post operative } \\
\text { deaths }\end{array}$} & \multirow{2}{*}{$\begin{array}{l}\text { Survival not } \\
\text { stated }\end{array}$} & \multicolumn{2}{|c|}{ Survival } & \multirow{2}{*}{$\begin{array}{l}\text { Mean (range) } \\
\text { (months) }\end{array}$} \\
\hline & & & & $1 y$ & $2 y$ & \\
\hline Excisional surgery & 40 & 9 & 3 & 4 & 1 & $\begin{array}{l}7.3 \\
(1-24)\end{array}$ \\
\hline Chemotherapy & 7 & & 3 & 0 & 0 & 7.2 \\
\hline Radiotherapy & 9 & & 1 & 0 & 0 & $\begin{array}{l}3.91 \\
(8 \mathrm{~d}-9 \mathrm{~m})\end{array}$ \\
\hline Chemotherapy and surgery & 1 & & & 0 & 0 & 4.5 \\
\hline Chemotherapy, surgery, and radiotherapy & $i$ & & & 0 & 0 & 6.5 \\
\hline Supportive treatment only & 9 & & & 0 & 0 & $\begin{array}{l}0.5 \\
(0-2)\end{array}$ \\
\hline Treatment not stated & 21 & & & 0 & 0 & $(6 \mathrm{~d}-6 \mathrm{~m})$ \\
\hline Treatment or survival not stated & 3 & & & & & \\
\hline
\end{tabular}


mixed, oat cell being combined with squamous or glandular components or both. Of the mixed tumours, 17 had areas of squamous differentiation and three glandular elements, and in three there was carcinoid differentiation. One patient showed squamous, glandular, and oat cell differentiation. The characteristic electron dense granules have been demonstrated ultrastructurally.

\section{Treatment and prognosis (table)}

No long term survival has been reported in patients with oat cell carcinoma of the oesophagus. Overall survival has been 4.7 (range 0-24) months. Forty patients have undergone oesophagectomy. There were nine postoperative deaths. Of the patients who left hospital after surgery, $82 \%$ have died within one year of diagnosis, the most (18 out of 23) dying within six months. The longest survival among the seven patients treated with chemotherapy alone was 11 months. Radiotherapy alone was used in nine patients. One patient was treated with chemotherapy followed by surgery and another was treated by a combination of chemotherapy, radiotherapy, and surgery. All but one of the patients had widespread lymphogenous and haematogenous metastases at death. Levenson et ${ }^{17}{ }^{17}$ reported a patient with supraclavicular lymph node metastases who was treated with multiagent chemotherapy and achieved a complete remission, confirmed at autopsy 11 months later, when he died in an accident.

\section{Discussion}

Small cell undifferentiated (oat cell) carcinoma of the oesophagus rarely occurs as a primary lesion. Although this tumour was described by McKeown ${ }^{1}$ 33 years ago, it has only recently been studied in detail. Careful light and electron microscopic examination has indicated morphological and histochemical characteristics indistinguishable from those of small cell carcinoma of the lung. ${ }^{78101214-1921-23252729}$

The clinical presentation of these oesophageal tumours appears to be similar to those of the more frequent squamous carcinomas and adenocarcinomas. As with other oesophageal carcinomas, ${ }^{1019}$ there was a preponderance of men $(60 \%)$.

The histogenesis of oat cell carcinoma remains to be elucidated. Two cases of oat cell carcinoma of the oesophagus were associated with ectopic endocrine syndromes ${ }^{1327}$; tissue analysis has revealed the presence of adrenocorticotrophic hormone in five ${ }^{5926}$ and calcitonin in one, ${ }^{18}$ without any clinical evidence of systemic endocrine hyperfunction. Oat cell carcinomas are therefore widely believed to be derived from the APUD (amine precursor uptake and decarboxylation) cells. 59121518212630 The embryog genesis of these cells has been a subject of controversy. Initially Pearse ${ }^{31}$ proposed a "neural crest" origin for these cells, but later work ${ }^{3032-34}$ has shown that APUD cells are in fact derived from endoderm. A푬 origin of oat cell carcinoma from "basal" cells wit pluripotentiality, or multipotential cells, has bee suggested by some authors ${ }^{813212329}$ to explain the mixed type of tumour.

The clinical behaviour of oat cell carcinoma of the oesophagus is similar to that of oat cell carcinoma of the lung with rapid and widespread disseminationw Published reports strongly imply that occult metasta ses are present at the time of diagnosis in mose patients. ${ }^{1-29}$ Despite this four $(10 \%)$ of the operated patients lived for more than one year, while with other modes of treatment there were no survivors by one year. Complete remission confirmed by necropsy at 1 p months in one patient treated by multiagent chemotherapy ${ }^{17}$ is encouraging. Resection, if feasible appears to be the treatment of choice. Because of the possibility of occult metastases adjuvent chemo therapy might be worthwhile, although the smatb number of cases will make controlled trials difficult. In view of the radiosensitivity of small cell carcinomab radiotherapy should be considered for palliation of inoperable lesions.

\section{References}

1 McKeown F. Oat cell carcinoma of the oesophagus? J Pathol Bacteriol 1952;64:889-91.

2 Morson BC, Dawson IMP. Gastrointestinal Patholog Oxford: Blackwell Scientific Publications, 1972:43.

3 Taniguch K, Iwanaga T, Kosaki G, et al. Oat cell car cinoma of the oesophagus producing ACTH. Report of two cases. Saishin-Igaku 1973;28:1834-7.

4 Turnbull AD, Rosen P, Goodner JT, Beattie EJ. Primar malignant tumours of the esophagus other than typicaD. epidermoid carcinoma. Ann Thorac Surg 1973;15. 463-73.

5 Watanabe H, Karasawa K, Okada Y, et al. Carcinoid and oat cell carcinoma of esophagus - with emphasis oP close relationship between both tumors. Japanese Journal of Cancer Clinics 1974;20:181-90.

6 Rosen Y, Moon S, Kim B. Small cell epidermoid car cinoma of the esophagus: an oat-cell-like carcinomifo Cancer 1975;36:1042-9.

7 Cook MG, Eusebi V, Betts CM. Oat-cell carcinoma of the oesophagus: a recently recognized entity. J Clif Pathol 1976;29:1068-73.

8 Matsusaka T, Watanabe H, Enjoji M. Anaplastic cars cinoma of the esophagus: report of three cases and the histogenetic consideration. Cancer 1976;37:1352-8.

9 Tateishi R, Taniguchi K, Horai T, et al. Argyrophil ceff carcinoma (apudoma) of the esophagus: a histo=0 pathologic entity. Virchows Arch A (Path Anat Histol $\Phi$ 1976;371:283-94.

10 Drut R. Oat cell carcinoma and mixed oat-cell epider moid carcinoma of the esophagus-a report of sevea 
cases. Pathologia Mexicana 1978;16:99-107.

11 Horai T, Kobayashi A, Tateishi R, et al. Cytologic study of small cell carcinoma of the esophagus. Cancer 1978;41:1890-6.

12 Imai T, Sannohe Y, Okano H. Oat cell carcinoma (apudoma) of the esophagus - a case report. Cancer 1978;41:358-64.

13 Reyes CV, Jao W, Gould VE. Neuroendocrine carcinomas of the esophagus. Ultrastructural Pathology 1980;1:367-76.

14 Kelsen DP, Weston E, Kurtz R, Cvitkovic E, Lieberman P, Golbey RB. Small-cell carcinoma of the esophagustreatment by chemotherapy alone. Cancer 1980;45: 1558-61.

15 Reid HAS, Richardson WW, Corrin B. Oat cell carcinoma of the esophagus. Cancer 1980;45:2342-7.

16 Chaudhry AP, Satchidanand S, Prezyna A, Alder RH. Oat cell carcinoma (apudoma) of esophagus - an ultrastructural study. NY State J Med 1981;81:1212-7.

17 Levenson RM, Ihde DC, Matthews MJ, et al. Small cell carcinoma presenting as an extrapulmonary eoplasm: sites of origin and response to chemotherapy. J Natl Cancer Inst 1981;67:607-12.

18 Rivera F, Matilla A, Fernandez-Sanz J, Galera H. Oat cell carcinoma of the esophagus. Virchows Arch (Pathol Anat) 1981;391:337-44.

19 Scarani P, Betts CM, Fedeli F, Bondi A. Oat cell carcinoma of the esophagus. Report of a case. Tumori 1981;67:599-603.

20 Sarma DP. Oat cell carcinoma of the esophagus. J Surg Oncol 1982;19:145-50.

21 Briggs JC, Ibrahim NBN. Oat cell carcinoma of the oesophagus: a clinico-pathological study of 23 cases. Histopathology 1983;7:261-77.

22 Rosenthal SN, Lemkin JA. Multiple small cell carcinomas of the esophagus. Cancer 1983;51:1944-6.

23 Tanoue S, Shimoda T, Suzuki M, Ikegami M, Ishikawa
E, Sano T. Anaplastic carcinoma of the oesophagus. Acta Pathol Jpn 1983;33:831-41.

24 Nakanuma Y, Ohta G, Sakata N, Sakuma H, Shintani T. An autopsy case of small cell carcinoma of the esophagus and a review of literature. Nippon Shokakhyo Gakkai 1984;81:263-6.

25 Karnad A, Poskitt JR. Small cell carcinoma of the esophagus: case report and review of the literature. Journal of the Tennessee Medical Association 1984;77:451-3.

26 Johnson FE, Clawson MC, Bashiti HM, Silverberg AE, Broun GO. Small cell undifferentiated carcinoma of the esophagus: case report with hormonal studies. Cancer 1984;53:1746-51.

27 Doherty MA, McIntyre M, Arnott SJ. Oat cell carcinoma of esophagus: a report of six British patients with a review of the literature. Int $J$ Radiation Oncology Biol Phys 1984;10:147-52.

28 Tan J, Mackenzie I, Duvall E. Metastatic small cell carcinoma of the temporal bone-a case report. $J$ Larynol Otol 1984;98:1267-71.

29 Ho KJ, Herrera GA, Jones JM, Alexander CB. Small cell carcinoma of the esophagus: evidence for a unified histogenesis. Hum Pathol 1984;15:460-8.

30 Ibrahim NBN, Briggs JC, Corbishley CM. Extrapulmonary oat cell carcinoma. Cancer 1984;54:1645-61.

31 Pearse AGE. Common cytochemical properties of cells producing polypeptide hormones (the APUD series) and their relevance to thyroid and ultimobranchial C-cells and calcitonin. Proc R Soc Med (Biol) 1968;170:71-80.

32 Sidhu GS. The endodermal origin of digestive and respiratory tract APUD cells. Am J Pathol 1979;96:5-17.

33 Andrew A. A study of the developmental relationship between enterochromaffin cells and the neural crest. $J$ Embryol Exp Morphol 1963;11:307-24.

34 Le Douarin NM, Teillet M. The migration of neural crest cells to the wall of the digestive tract in avian embryo. $J$ Embryol Exp Morphol 1973;30:31-48. 